\title{
EVALUATION OF METAL AFFINITY OF COPPER AND ZINC IN PARTICLE PRODUCED FROM THERMALLY CROSSLINKED SERICIN-ALGINATE BLEND
}

\author{
T. L. da SILVA ${ }^{1}$, A. CARVALHO ${ }^{1}$, M. F. RAGASSI ${ }^{1}$, M. F. de A. TOLEDO ${ }^{1}$, J. O. \\ LIMA $^{1}$, M. L. GIMENES ${ }^{2}$, M. G. A. VIEIRA ${ }^{1}$ and M. G. C. da SILVA ${ }^{1}$ \\ ${ }^{1}$ University of Campinas, School of Chemical Engineering \\ ${ }^{2}$ State University of Maringá, Departament of Chemical Engineering \\ E-mail address: meuris@feq.unicamp.br
}

\begin{abstract}
Sericin is a protein present in the cocoon of silkworm silk (Bombyx mori), usually discarded in the effluent from the spinning process. The use of blends provides an improvement in the physical characteristics of the materials produced with the protein, and the use of alginate has the advantage because it has affinity for a variety of cations. The objective of this study is to evaluate the process of thermal crosslinking of the particles produced from the blend between sericin and alginate and metal affinity of these particles with zinc and copper metals. For this purpose, we evaluated the crosslinking temperatures of $40,100,125$ and $150{ }^{\circ} \mathrm{C}$. Subsequently, the particles were analyzed for the water solubility and its ability to adsorb metals in aqueous solution. The results indicated that the particles cross-linked at $100{ }^{\circ} \mathrm{C}$ had smaller percentage of solubilized matter comparing with other temperatures. The results indicated that sericin/alginate particles had greater affinity to $\mathrm{Cu}^{2+}$ than to $\mathrm{Zn}^{2+}$ ions.
\end{abstract}

\section{INTRODUCTION}

Heavy metals are pollutants intensively studied due to their significance from the point of view of persistence and toxicity (Nitã et al., 2007). This kind of contamination is toxic to aquatic flora and fauna even in relatively low concentration. Furthermore, some metals can be assimilated, stored and concentrated by organisms (Mohan et al., 2005) leading severe impacts in the environment and human health (Kwak et al., 2013). Some health problems related to toxic metals include accumulative poisoning, cancer, damages in brain, kidneys and bones, among others, depending on the level of contamination (Nitã et al., 2007; Mohan et al., 2005).

Industries, including mining, electroplating, fertilizer manufacturing and petroleum refining have in their effluents high levels of heavy metals that can contaminate the environment (Mohan et al., 2005). For diluted metal concentrations, ion exchange, reverse osmosis and adsorption can be applied to decontamination (Nitã et al., 2007). The adsorption has the advantage of be most inexpensive among the other two methods, plus the ability to use the biosorbents from agriculture, biomass and industrial waste. The use of biosorbents in adsorption processes have been considered attractive because the low-cost materials for treatment of wide range of pollutants, including dyes, pesticides and metal ions (Chen et al., 2011). The sericin and alginate are focus of many researches due their characteristics and interaction with metals and dyes.

Sericin is a globular protein that constitutes $25-30 \%$ of silk protein of silkworm 
cocoon (Bombyx mori). Most of the sericin is removed during the silk processing and it is usually discarded in the wastewater. Annually, it is estimated that about 50,000 tons of sericin is produced and not recovered from the effluents of degumming process (Zhang, 2002). It consists of 18 amino acids, most of which have strong polar side chains such carboxyl, hydroxyl and amino groups that allow easy cross-linking, copolymerization and blending with other polymers to form improved biodegradable materials (Aranwit et al., 2012; Dash et al., 2009; Zhang, 2002).

Alginate is a biopolymer extracted from brown seaweed and it is composed of regions of sequential $\beta$-D-mannuronic acid monomers (M-blocks) regions of $\alpha$-L-guluronic acid (Gblocks), and regions of interspersed M and G units (Khandai et al., 2010; Nitã et al., 2007). The linear polysaccharide has advantages, such as facile obtaining procedure, biodegradability, biocompatibility, economic and environmental friendly characteristics (Nitã et al., 2007). Alginates undergo gelation in aqueous solution, under mild conditions, through interaction with divalent cations, such as calcium, that can cooperatively bind between the G-blocks of adjacent alginate chains creating ionic inter-chain bridges (Khandai et al., 2010).

The affinity of sericin and alginate for metals had been studied in recent years. Kwak et al. (2013) utilized sericin beads fabricated using a $1 \mathrm{M} \mathrm{LiCl} / \mathrm{DMSO}$ solvent and utilized as a adsorbent to Chromium(VI) and the maximum adsorption capacity found was 33.76 mg. $\mathrm{g}^{-1}$ at $\mathrm{pH}$ 2. Chen et al. (2011) using powder of sericin and chitosan observed that both biosorbents displayed good capacity for gold adsorption of 1.0 and $3.3 \mathrm{mmol} . \mathrm{g}^{-1}$ of gold, respectively. Nitã et al. (2007) utilized calcium alginate microparticles to evaluate adsorption of $\mathrm{Pb}^{+2}$ and $\mathrm{Cd}^{+2}$ ions and concluded that this kind of particle can be a suitable alternative to remove heavy metal from industrial wastewater.

Thus, the objective of this study is to evaluate the production of particle from sericin and alginate blend with thermal crosslinking. The blend was dropped in alcoholic (ethanol) and aqueous solutions of $\mathrm{CaCl}_{2}$ and the particles were dried at $40,100,125$ and $150{ }^{\circ} \mathrm{C}$. The particles were analyzed for the water solubility and its ability to adsorb metals $\left(\mathrm{Zn}^{+2}\right.$ and $\mathrm{Cu}^{+2}$ ) in aqueous solution, by metallic affinity tests.

\section{MATERIALS AND METHODS}

The Bombyx mori silkworm's cocoons were kindly provided by Bratac Silk Mills Company, located in the State of Paraná - Brazil.

\subsection{Preparation of particles}

The cocoons were manually cleaned and cut into small pieces (about $1 \mathrm{~cm}^{2}$ ) and then, they were carefully washed with tap water and rinsed with deionized water for three times. The cocoons were dried overnight at $50{ }^{\circ} \mathrm{C}$, until they reach a constant weigh. After that, they were weighed and immersed in ultrapure water, in the ratio 4:100 w/V $(\mathrm{g} / \mathrm{mL})$, in order to be used in the degumming process. The sericin solution (SS) was extracted using an autoclave (LS - Logen Scientific, LS1 model) at $120^{\circ} \mathrm{C}\left(1 \mathrm{kgf} / \mathrm{cm}^{2}\right)$ for 40 minutes. The processing time started to be measured after the system had reached the desired temperature and pressure. The SS was vacuum filtered to remove the fibers from the solution, stored in a sealed container, and then it was maintained at room temperature for at least 12 hours to stabilize the hydrogel. After this period the SS was frozen in a conventional freezer for at least $24 \mathrm{~h}$ and then it was thawed at room temperature. The precipitated sericin was vacuum 
filtered, heated in autoclave $\left(120^{\circ} \mathrm{C}, 10 \mathrm{~min}\right)$ to solubilize the precipitated protein, and then, the solution was adjusted to $2.5 \% \mathrm{w} / \mathrm{V}$. The sodium alginate was added in concentration of $2 \% \mathrm{w} / \mathrm{V}$ in the adjusted sericin solution. The particles were prepared by ionic gelation process, in which, the blend was dripped, with an peristaltic pump, in aqueous and alcoholic (ethanol) solution of $\mathrm{CaCl}_{2}(3 \% \mathrm{w} / \mathrm{V})$ and then it was magnetic stirred for $24 \mathrm{~h}$ in its respective solution. Both particles were dried at room temperature and, posteriorly, in order to perform the crosslinking process, the particles were heated (in a continuous flow oven) at $40,100,125$ and $150^{\circ} \mathrm{C}$ for $24 \mathrm{~h}$. After this period, the wet and dried particles were analysed by water solubility and their affinity with $\mathrm{Cu}^{2+}$ and $\mathrm{Zn}^{2+}$ through adsorption tests.

\subsection{Percentage of humidity $(\omega)$ and Solubility in water $\left(\mathrm{S} \omega\right.$ and $\left.S_{\mathrm{D}}\right)$}

The wet particles were collected and washed with deionized water for 10 minutes in magnetic stirring before the thermal cross-linking process and affinity metals tests. After the washing process, the particles were rinsed with deionized water and placed on adsorbent paper to remove the surface moisture. To calculate $\omega$ and $S \omega$, samples of washed particles were placed on absorbent filter paper to remove the surface moisture and the initial mass was determined: $\mathrm{m}_{0 \omega}$ and $\mathrm{m}_{0 \mathrm{~s}_{\omega}}$, to $\omega$ and $\mathrm{S} \omega$, respectively. The percentage of humidity $(\omega)$ was obtained by Eq. (1), where, $\mathrm{m}_{\mathrm{F} \omega}$ is the weight of dry particles after $24 \mathrm{~h}\left(105^{\circ} \mathrm{C}\right)$ in continuous flow oven.

$\omega=\frac{\left(m_{0 \omega}-m_{F \omega}\right)}{m_{0 \omega}}$

The percentage of solubilized matter of wet particles $(\mathrm{S} \omega)$ - water solubility - was determined by Eq. (2), adapting the procedure adopted by Turbiani et al. (2011). Samples of wet particles $\left(\mathrm{m}_{0 \mathrm{~s}_{\varpi}}\right)$ were immersed in $100 \mathrm{~mL}$ of ultrapure water using Erlenmeyer of 125 $\mathrm{mL}$ and then these recipes were maintained under agitation $(200 \mathrm{rpm})$ at $25{ }^{\circ} \mathrm{C}$ for $24 \mathrm{~h}$. After this period, the particles were dried for $24 \mathrm{~h}$ at $105^{\circ} \mathrm{C}$ and the final weight was measured $\left(\mathrm{m}_{\mathrm{Fs}_{\varpi}}\right)$. The percentages of solubilized matter of dry particles (SD) are similarly measured by Eq. (3). The particles produced in alcohol and aqueous $\mathrm{CaCl}_{2}$ solutions, after washing process, were dried in different temperatures and an initial sample $\left(m_{S O D}\right)$ was immersed in $100 \mathrm{~mL}$ of ultrapure water for agitation $\left(200 \mathrm{rpm}, 24 \mathrm{~h}, 25^{\circ} \mathrm{C}\right)$. Posteriorly, the particles were dried again $\left(105^{\circ} \mathrm{C}, 24 \mathrm{~h}\right)$ and the final weight was measured $\left(\mathrm{m}_{\text {SFD }}\right)$. All analyses were performed in triplicate.

$$
\begin{aligned}
& S_{\omega}=\frac{m_{0 S_{\omega}} \cdot(1-\omega)-m_{F S_{\omega}}}{m_{0 S_{\omega}} \cdot(1-\omega)} \\
& S_{D}=\frac{m_{S O D^{*}}-m_{S F D}}{m_{S O D}}
\end{aligned}
$$

\subsection{Metal Affinity Test}

Metal speciation diagrams as a function of $\mathrm{pH}$ were simulated using the Hydra and Medusa software (Puigdomenech, 2004) to identify the different species in aqueous metals 
solutions in order to choose the $\mathrm{pH}$ interval in which chemical precipitation does not occur.

The metal solutions of $1 \mathrm{mmol} . \mathrm{L}^{-1}$ of $\mathrm{Cu}^{2+}$ and $\mathrm{Zn}^{2+}$ were prepared by dissolving the salts nitrate $\mathrm{Cu}(\mathrm{NO} 3)_{2} \cdot 3 \mathrm{H}_{2} \mathrm{O}$, and $\mathrm{Zn}(\mathrm{NO} 3)_{2} \cdot 6 \mathrm{H}_{2} \mathrm{O}$ in ultrapure water (Mili-Q). Samples of $0.5 \mathrm{~g}$ of each particle were immersed in $50 \mathrm{~mL}$ of metal solution (zinc and copper solutions) using Erlenmeyer flasks of $125 \mathrm{~mL}$ and then these recipes were maintained under agitation (200 rpm) at $25^{\circ} \mathrm{C}$ for $24 \mathrm{~h}$. After, the liquid fase was centrifuged for $10 \mathrm{~min}$ at $4000 \mathrm{rpm}$. All metal concentrations were measured at atomic absorption spectroscopy (AAS) Shimadzu Atomic Absorption Spectrophotometer GFA 7000A. The adsorption capacity of the particles $\left(\mathrm{q}_{\mathrm{e}}\right)$, in the evaluated conditions, and the percentage removal $(\% \mathrm{R})$ are determined by Equations 4 and 5, respectively. Solutions of nitric acid were used to control $\mathrm{pH}$ during the experiment.

$q_{e}=\frac{\left(C_{0}-C_{e}\right) \cdot V}{m_{p}}$

Where, $\mathrm{C}_{0}$ is the initial concentration, $\mathrm{C}_{\mathrm{e}}$ is the equilibrium concentration (after $24 \mathrm{~h}$ ), $\mathrm{V}$ is the volume in each Erlenmeyer flask $(50 \mathrm{~mL})$, and $\mathrm{m}_{\mathrm{p}}$ is the dry mass of alginate-sericin particles $(0.5 \mathrm{~g})$.

$\% R=\frac{\left(C_{0}-C_{e}\right)}{C_{0}} \times 100$

\section{RESULTS AND DISCUSSION}

Table 1 shows the results of percentage of humidity $(\omega)$ and percentage of solubilized matter (water solubility - S $\omega$ ) of wet particles produced from sericin and alginate blend by ionic gelation technique (dripping in aqueous and alcoholic solution).

Table 1: Percentage of wet particles $(\omega)$, solubility in water of wet particles $\left(S_{\omega}\right)$.

\begin{tabular}{ccc}
\hline Dripping in: & Aqueous $\mathrm{CaCl}_{2}$ solution & Alcoholic $\mathrm{CaCl}_{2}$ solution \\
\hline$\omega(\%):$ & $95.2 \%$ & $94.0 \%$ \\
\hline $\mathrm{S}_{\omega}(\%):$ & $10.3( \pm 0.4) \%$ & $14.0( \pm 0.5) \%$ \\
\hline
\end{tabular}

Table 2 shows the results of percentage of solubilized matter (water solubility $-\mathrm{S}_{\mathrm{D}}$ ) of particles after the thermal crosslinking processes.

Table 2: Percentage of solubilized matter $\left(\mathrm{S}_{\mathrm{D}}\right)$ of thermal cross-linked particles at 40 , 100,125 and $150{ }^{\circ} \mathrm{C}$.

\begin{tabular}{ccc}
\hline $\begin{array}{c}\text { Temperature of } \\
\text { crosslinking process }\end{array}$ & $\begin{array}{c}\mathrm{S}_{\mathrm{D}}(\%) \text { of particles produced } \\
\text { in aqueous } \mathrm{CaCl}_{2} \text { solution }\end{array}$ & $\begin{array}{c}\mathrm{S}_{\mathrm{D}}(\%) \text { of particles produced } \\
\text { in alcoholic } \mathrm{CaCl}_{2} \text { solution }\end{array}$ \\
\hline $40^{\circ} \mathrm{C}$ & $12.5( \pm 0.2)$ & $10.8( \pm 0.1)$ \\
\hline $100^{\circ} \mathrm{C}$ & $7.3( \pm 0.1)$ & $5.0( \pm 0.1)$ \\
\hline $125^{\circ} \mathrm{C}$ & $10.2( \pm 0.2)$ & $7.3( \pm 0.1)$ \\
\hline $150^{\circ} \mathrm{C}$ & $30.7( \pm 0.4)$ & $24.8( \pm 0.2)$ \\
\hline
\end{tabular}

As seen in Table 1, despite the little difference between the values, the water solubility 
$(\mathrm{S} \omega)$ of the particles was smaller when particles were prepared in aqueous $\mathrm{CaCl}_{2}$ solution $(3 \% \mathrm{w} / \mathrm{V})$. In Table 2 , the results shows that after the crosslinking process, the particles that were produced in alcoholic $\mathrm{CaCl}_{2}$ solution presented $\mathrm{S}_{\mathrm{D}}$ values smaller than the ones prepared in aqueous $\mathrm{CaCl}_{2}$ solution.

According to Aranwit et al. (2012) and Gimenes et al. (2007), alcohol changes the structure of proteins, inducing organized $\beta$-sheet formation, what can decrease the solubility in water. In dried particles, these changes seem to help the crosslinking process. Lower $\mathrm{S}_{\mathrm{D}}$ values were obtained when the particles were cross-linked at $100{ }^{\circ} \mathrm{C} ; 7.3 \%$ and $5.0 \%$ to particles produced in aqueous and alcoholic $\mathrm{CaCl}_{2}$ solutions, respectively. The thermal process of crosslinking decreases the percentage of solubility in particles dried at $100{ }^{\circ} \mathrm{C}$, but higher temperatures increase the solubility of particles. As related by Aranwit et al. (2012), heating favours crosslinking by disrupting the protein structure and exposing the sulfhydryl and hydrophobic groups, resulting in the formation of disulphide linkages. The cross-linked particles at 125 and $150{ }^{\circ} \mathrm{C}$ had a darker color than the ones cross-linked at 40 and $100{ }^{\circ} \mathrm{C}$. The changes observed in color and structure of particles dried at 125 and $150{ }^{\circ} \mathrm{C}$, probably are related with the Maillard reactions that occur with proteins and polysaccharides in heating processes. This reaction reduces sugar, condensing with compounds possessing a free amino group (of an amino acid or in proteins mainly in E-amino group and a-amino groups of terminal amino acids), and, in advanced stages a range of reactions takes place, including cyclisations, dehydrations, retroaldolisations, rearrangements, isomerisations and further condensations, which ultimately, in a final stage, leads to the formation of brown nitrogenous polymers and co-polymers (Martins et al., 2001). Maillard reactions probably are related with changes in particle exposed to heat for a long period of time and high temperature $\left(24 \mathrm{~h}, 150{ }^{\circ} \mathrm{C}\right)$ causing an increase in solubility observed. It is important to notice that the metal solutions in which affinity tests of dried particles was executed, at 125 and $150{ }^{\circ} \mathrm{C}$, had a brown color after the period of $24 \mathrm{~h}$, because the solubilized matter of particles.

Figure 1 shows the fraction of metallic speciation diagrams as a function of $\mathrm{pH}$ simulated by HYDRA software.

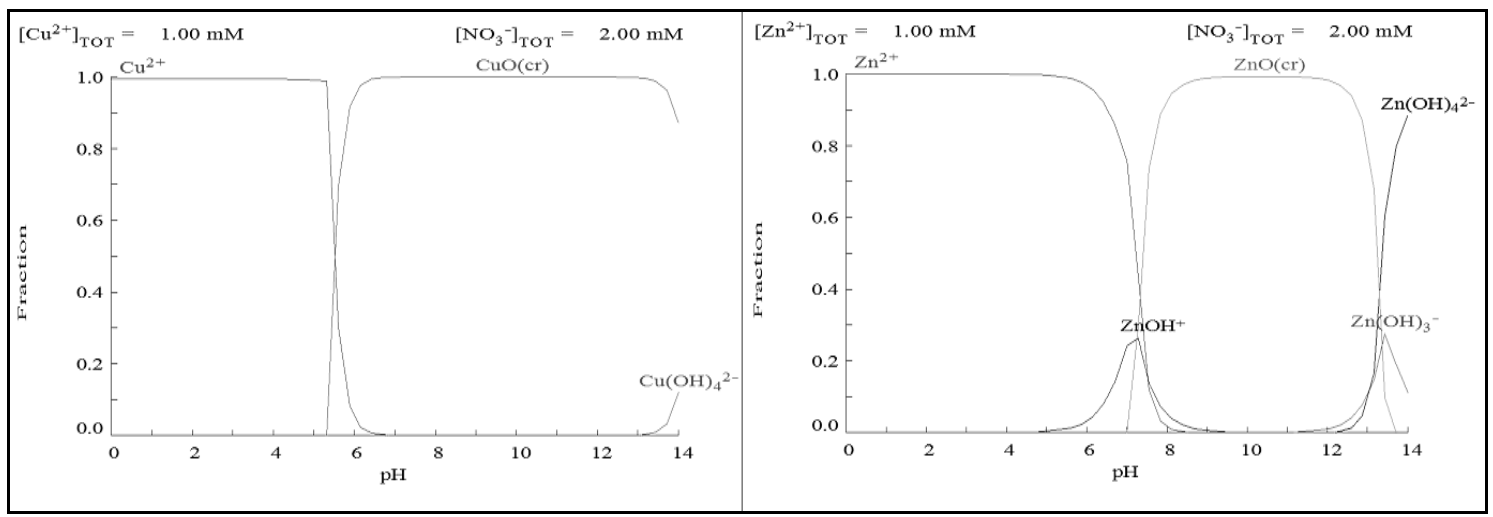

Figure 1: Metal speciation of copper and zinc as function of $\mathrm{pH}$.

From Figure 1, it can be seen that the $\mathrm{Cu}^{2+}$ and $\mathrm{Zn}^{2+}$ fractions occurs in $\mathrm{pH}$ less than 5 . Therefore, in order to evaluate the adsorption of these metals in affinity test, the $\mathrm{pH}$ was adjusted and controlled during the experiments with $\mathrm{HNO}_{3}$ solution to values of approximately $4.0 \sim 4,5$. This procedure was adopted to avoid the chemical precipitation that can occur in $\mathrm{pH}$ higher than, approximately, 5 to copper and to avoid the formation of $\mathrm{ZnOH}^{-}$specie to zinc. 
Figure 2 and 3 show the adsorption capacity and reduction of the concentration of $\mathrm{Cu}^{2+}$ and $\mathrm{Zn}^{2+}$ by particles produced from sericin and alginate in aqueous and alcoholic $\mathrm{CaCl}_{2}$ solutions, respectively.

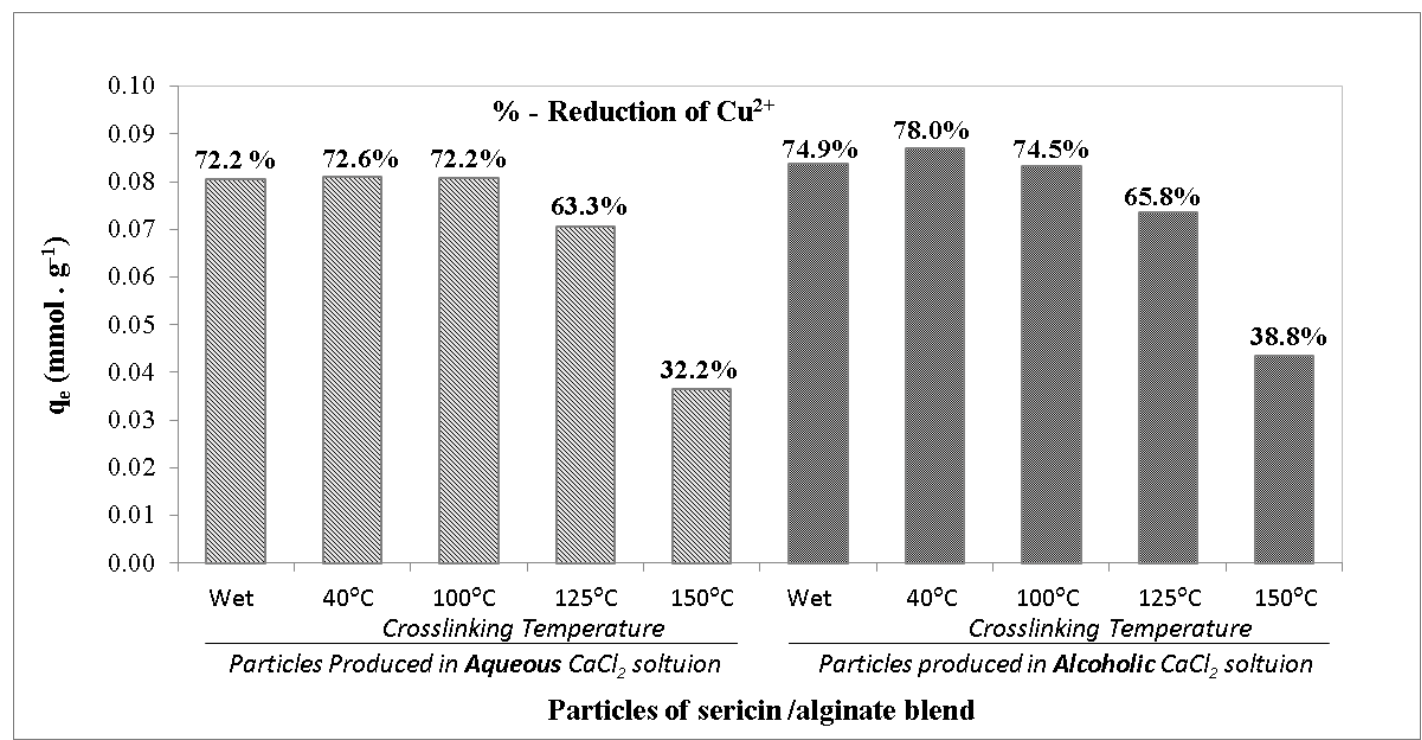

Figure 2: Adsorption capacity $\left(\mathrm{q}_{\mathrm{e}}\right)$ and reduction of the concentration $(\%)$ of $\mathrm{Cu}^{2+}$ in the copper tests affinity for wet particles and particles thermally cross-linked at 40, 100, 125 and $150^{\circ} \mathrm{C}$.

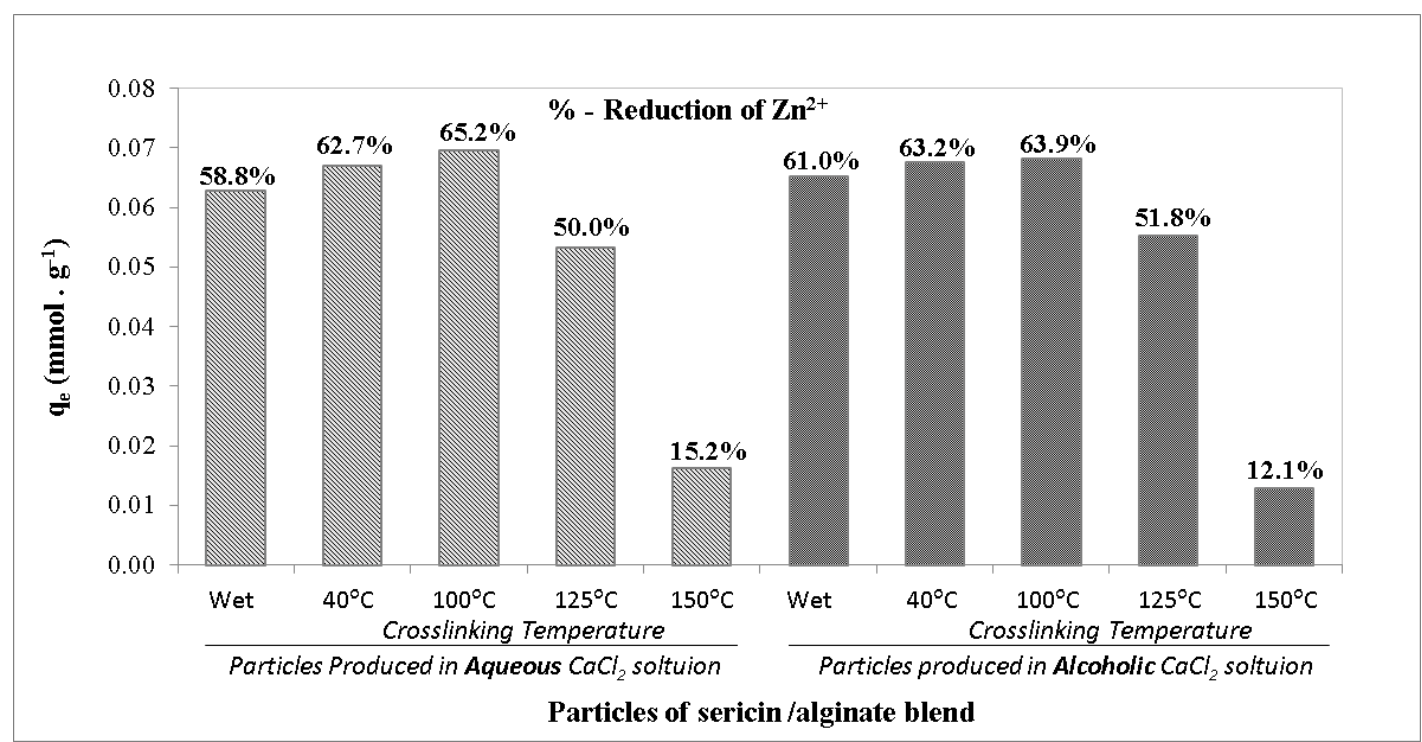

Figure 3: Adsorption capacity $\left(\mathrm{q}_{\mathrm{e}}\right)$ and reduction of the concentration $(\%)$ of $\mathrm{Zn}^{2+}$ in the zinc tests affinity for wet particles and particles thermally cross-linked at 40, 100, 125 and $150^{\circ} \mathrm{C}$.

In Figure 2, we observed that the wet particle and the particles cross-linked at 40 and $100{ }^{\circ} \mathrm{C}$ had similar results. When the particles was produced in alcoholic $\mathrm{CaCl}_{2}$ solution, there is a little increase in the capacity of adsorption and an increase in the reduction of the concentration of $\mathrm{Cu}^{2+}$, comparing the results obtained with particles cross-linked in the same temperature. The reduction of $63.3 \%, 32.2 \%$ (to particles produced in aqueous $\mathrm{CaCl}_{2}$ solution) and $65.8 \%, 38.8 \%$ (to particles produced in alcoholic particles) observed in the concentration of $\mathrm{Cu}^{2+}$ in the particles cross-linked at 125 and $150{ }^{\circ} \mathrm{C}$ were smaller than the 
reduction promoted by particles cross-linked at $40,100{ }^{\circ} \mathrm{C}$ and wet particles. Probably, as discussed previously, the changes promoted by Maillard reactions in cross-linked particles at 125 and $150^{\circ} \mathrm{C}$ are responsible for the decrease of adsorption capacity of particles.

Figure 3 shows the results of affinity of the sericin/alginate particles by $\mathrm{Zn}^{2+}$. Similar seen in Figure 2, in affinity tests with $\mathrm{Zn}^{2+}$, the cross-linked particles at 40 and $100{ }^{\circ} \mathrm{C}$ presents a greater adsorption capacity than the ones cross-linked at 125 and $150{ }^{\circ} \mathrm{C}$. The $\mathrm{q}_{\mathrm{e}}$ values to particles cross-linked in $150{ }^{\circ} \mathrm{C}$ were very small to both particles: $15.2 \%$ and $12.1 \%$ to particles produced in aqueous and alcoholic solutions before drying process. Probably, it is due the changes that the high temperature and the long period of time promoted during the crosslinking process $\left(150^{\circ} \mathrm{C}, 24 \mathrm{~h}\right)$ at these particles.

Comparing the results in Table 2 and the results showed in Figures 2 and 3, it is possible to see that the best crosslinking temperature was $100{ }^{\circ} \mathrm{C}$ to produce particles. In this temperature the $S_{D}$ value was smaller than in the other temperatures, what is very important in continuous and batch adsorption processes. Furthermore, the adsorption capacity of particles cross-linked in this temperature presented good values, comparing with the adsorption capacity of the other particles.

In general, the adsorption capacity of particles by $\mathrm{Zn}^{2+}$ was smaller than the ones by $\mathrm{Cu}^{2+}$. The particles produced from the sericin and alginate blend had major affinity by $\mathrm{Cu}^{2+}$ than to $\mathrm{Zn}^{2+}$. Comparing the particles cross-linked in the same temperature, all had best affinity to $\mathrm{Cu}^{2+}$ than to $\mathrm{Zn}^{2+}$.

\section{CONCLUSION}

The dried particles produced from sericin/alginate blend in alcoholic $\mathrm{CaCl}_{2}$ solution showed smaller solubility in water than the ones produced in aqueous solution. When the particles were cross-linked at $100{ }^{\circ} \mathrm{C}$, the $\mathrm{S}_{\mathrm{D}}$ results reached the smaller values. The crosslinking process at $150{ }^{\circ} \mathrm{C}$ promotes changes in the structure of particles that increases the water solubility and decreases its adsorption capacity. The tests indicated that the particles of sericin/alginate had major affinity to $\mathrm{Cu}^{2+}$ than $\mathrm{Zn}^{2+}$, because comparing particles cross-linked at the same temperature, the reduction observed in concentration of $\mathrm{Cu}^{2+}$ were greater than the ones observed in $\mathrm{Zn}^{2+}$ solutions.

\section{ACKNOWLEDGEMENTS}

The authors would like to thank Bratac Silk Mills Company for providing us silkworm cocoons, CNPq, FAPESP and Fundação Araucária for the financial support.

\section{REFERENCES}

ARAMWIT, P., SIRTIENTONG, T., SRICHNA. Potencial applications of silk sericin a natural protein from textile industry by-products. Waste management and Research. 30 (3), 217-224. 2012.

CHEN X., LAM K. F., MAK S. F. YEUNG K. L. Precious metal recovery by selective adsorption using biosorbents, Journal of Hazardous Materials, 186, 902-910, 2011.

DASH, B.C., MANDAL, B.B., KUNDU, S.C. Silk gland sericin protein membranes: Fabrication and characterization for potential biotechnological applications, Journal of 
Biotechnology. 144, 321-329, 2009.

GIMENES, M.L.; LIU, L.; FEN, X. Sericin/poly(vinyl alcohol) blend membranes for pervaporation separation of etanol/water mixtures. Journal of Membrane Science, 295, p. 71-79, 2007.

KHANDAI M., CHAKRABORTY S., SHARMA A., PATTNAIK S., PATRA C. N., DINDA S. C., SEN K. K. Preparation and evaluation of algino-sericin microspheres: An approach for sustained drug delivery. Journal of Advanced Pharmaceutical Research, 1, 4860, 2010.

KWAK, H. W., YANG, Y.S., KIM, M.K., LEE, J.Y., YUN, H., KIM, M.H., LEE, K.H. Chromium (IV) adsorption behavior of silk sericin beads. International Joournal of Industrial Entomology. 26 (1), p. 47-53, 2013.

MARTINS, S.I.F.S.; JONGEN, W.M.F.; BOEKEL, M.A.J.S. A review of Maillard reaction in food and implications to Kinect modelling. Trends in Food Science and Technology. 11, p. 364-373, 2001.

MOHAM, D., PITTMAN Jr., C.U., STEELE, P.H. Single, binary and multi-component adsorption of cupper and cadmium from aqueous solutions on kraft lignin - a biosorbent. Journal of Cooloid and Interface Science. 297, p. 489 - 504, 2006.

NITÃ, I.; IORGULESCU, M.; SPIROIU, M. F.; GHIUREA, M.; PETCU, C.; CINTEZÃ, O. The adsorption of heavy metal ions on porous calcium alginate microparticles. Analele Universitatii din Bucuresti, Anul XVI, vol. 1, p. 59-67, 2007.

SAROVART, S., SUDATIS, B., MEESILPA, P., GRADY, B.P., MAGARAPHAN, R. The use of sericin as an antioxidant and antimicrobial for polluted air treatment. Rev. Adv.Mater.Sci., (5), p. 193-198, 2003.

TURBIANI, F.R.B, TOMADON JR, J., SEIXAS, F.L., GIMENES, M.L. Properties and Structure of Sericin Films: Effects of the Crosslinking Degree. AIDIC, Mechanical \& Chemical Engineering Transactions. 24, 1489-1494, 2011.

ZHANG, Y.Q. Applications of natural silk sericin in biomaterials, Biothechnology Advances. 20, 91-100, 2002. 